\title{
Contribution of the "Institut Scientifique Chérifien" to the development of geoscientific research in Northwest Africa since its creation in 1914
}

\author{
F. Medina \\ Rue Oued Draa, no. 28, Appt. 1, Agdal, Rabat, Morocco \\ Correspondence to: F. Medina (medinafida@yahoo.com)
}

Received: 9 May 2013 - Revised: 20 July 2013 - Accepted: 24 July 2013 - Published: 16 August 2013

\begin{abstract}
The contribution of the "Institut Scientifique Chérifien", the oldest scientific research centre in Morocco, is reviewed since its creation almost a century ago. Planned in 1914 by the French protectorate of Morocco, this institute has played, since its effective creation in 1920, an important role in the development of several geosciences in North Africa, such as meteorology and climatology, geophysics (gravimetry, magnetism and especially seismology), geomorphology, geology and oceanography. After the independence of Morocco in 1955, several activities, such as meteorology, were transferred elsewhere, but others, such as seismology and magnetism, remained important elements of the centre until recent years. In addition to the research activities, its observatories and libraries that were built during the early years are unique in Northwest Africa.
\end{abstract}

\section{Introduction: historical setting}

By the early years of the 20th century, Morocco was invaded by French troops, and the Fes Treaty was signed on 30 March 1912, by which the French Protectorate of Morocco was established. After the rapid installation of the French administration, the geologist Louis Gentil (1868-1925), who was the scientific advisor of General Hubert Lyautey, the general resident of the Protectorate, suggested in 1913 to the central government of Morocco the creation of a scientific body whose objective would be the inventory of the Moroccan flora, fauna and soil. The projected scientific centre, initially called "Institut des recherches scientifiques du Protectorat" was formally included in chapter XXI of the budget of the Protectorate on 31 July 1914 (Gotteland, 1931). The institute started its work with a very small budget and only in the geological domain. However, because of the involvement of France in World War I, the official creation of the institute was postponed until 24 January 1920, according to a circular signed by General Lyautey (Gotteland, 1931). Dr. Charles Liouville (1879-1960), a medical doctor and marine biologist (Fig. 1), was named on 3 February 1920 (Official Bulletin O.B. 380, p. 182) director of the "Institut Scientifique du Protectorat français au Maroc". The activities of the in- stitute, whose name was finally changed to "Institut Scientifique Chérifien" (abbreviated to ISC in the following) were defined by a Vizir by-law of 8 March 1921 (O.B. 437, p. 400), and Rabat, the growing administrative city, was chosen to be its location.

Since its creation almost a century ago, the "Institut Scientifique Chérifien" (shortened to "Institut Scientifique" in 1975) has played a major role in several biosciences such as botany and plant protection, zoology, parasitology, and also in geosciences such as meteorology, geophysics and geology. The research activity was parallel to, and often based on, continuous monitoring in meteorology, climatology and seismology.

This paper presents the $100 \mathrm{yr}$ long contribution of the "Institut Scientifique Chérifien" to the progress of geosciences in Morocco, and more generally, to the international scientific body of knowledge, with a special emphasis on the early years from its creation to the 1980s. However, only the major stages of the institution's history will be retraced, with a few references to the technical advances, which are beyond the scope of the paper. 


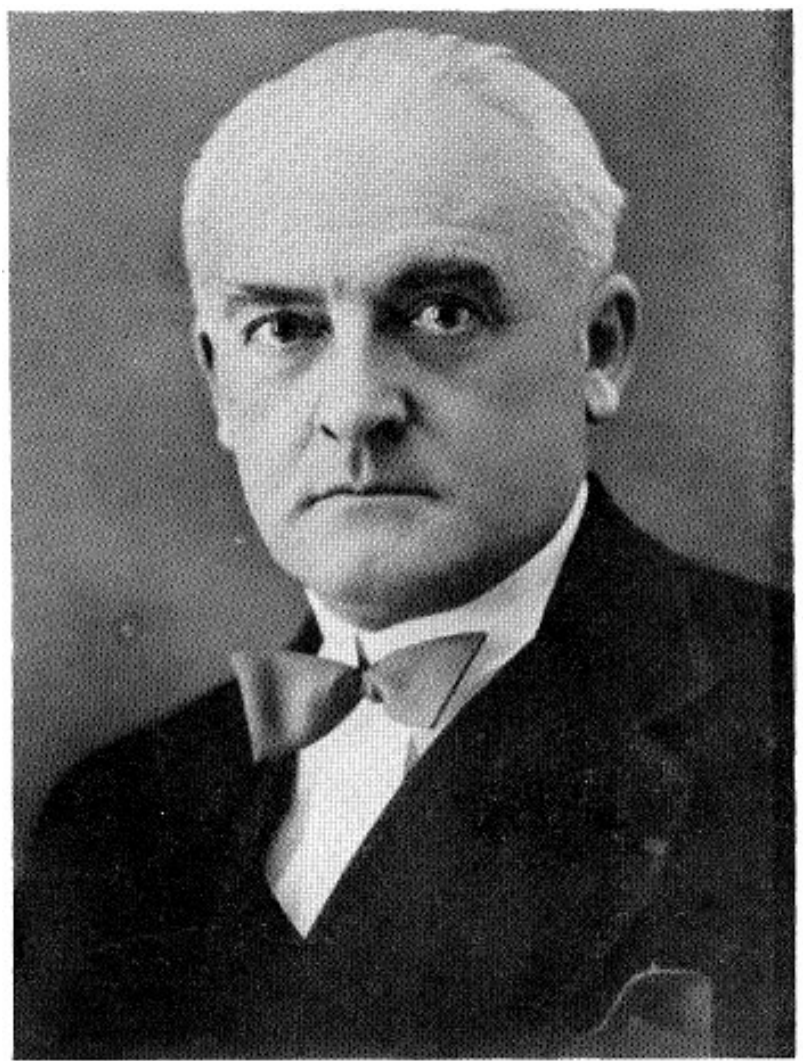

Figure 1. Portrait of Dr. Jacques Liouville (1879-1960), first director of the "Institut Scientifique Chérifien" (from his biography by $\mathrm{R}$. Ph. Dollfus published in the Bulletin de la Société des Sciences naturelles et physiques du Maroc, Tome 40, 4ème trimestre 1960).

\section{Geosciences during the early years of the ISC}

An extensive description of the birth and development of "modern" geosciences in Morocco can be found in the volume "Le Maroc Physique" (Gentil, 1912) and in a recent book chapter by Missenard et al. (2008). Summarizing, among the several "preliminary" - often secret - explorations at the end of the 19th and the dawn of the 20th centuries, the strictly geological campaigns were those of Thomson in 1889 (Travels in the Atlas and Southern Morocco, London), Brives in 1905 (Contribution à l'étude géologique de l'Atlas marocain), and especially Gentil $(1909,1912)$ whose observations were the most precise and widespread as he dared to explore the dangerous tribal territories which were not controlled by the Moroccan central government, in particular the Atlas Mountains.

Geological research seems to have been the main objective behind the creation of the ISC. In fact, Gentil attempted to found the first geological laboratory at Marrakech in 1907, but its establishment failed because of the unrest that followed the murder of Dr. Emile Mauchamp on 19 March of the same year, and the subsequent French invasion. The geo- scientific vocation of the ISC was clearly expressed in Article 2 of the Vizir by-law of 26 March 1921: "the institute has as objective to carry out research in [...], geology and mineralogy, astronomy and meteorology, physical geography and oceanography [...]". In addition, Article 6 of the same bylaw stated that the ISC should build a museum, a library and all the observatories necessary to its investigations.

From 1914 to 1920, the ISC was working as a small geological laboratory under the direction of Gentil, in continuation of the failed (ergo unofficial) geological service at Marrakech, with funds of some $100000 \mathrm{FF}$ (Gotteland, 1931). After the official creation, geological sciences were restricted to a small, though active, department (Service) successively under the responsibility of F. A. Rolland (1922-1924), Louis Gentil (1924-1925) until his death, and Jean Bourcart afterwards. The main reason for said restrictions is that the exploration of the Moroccan mineral resources and mapping was early assigned to much more powerful institutions such as the "Service Géologique du Maroc" (1921) whose director was Georges Marçais (who became director of the ISC in 1942), the "Office Chérifien des Phosphates" (1921), the "Bureau de Recherches et Participations Minières" for mining (1928), and the "Société Chérifienne des Pétroles" for petroleum exploration (1929).

Although the Moroccan meteorological network was already attached to the ISC in 1921, a crucial decision was the creation of a specific department for meteorology and geophysics, which was intended to provide information to the developing agricultural and aerial navigation activities. Hence, the decree of 5 August 1933 (O.B. 1085, p. 783) refers to the creation at Casablanca of the "section de physique du globe et de meteorology à l'Institut scientifique chérifien" (abbreviated to SPGM hereafter), with an observatory at Berrechid, located some $50 \mathrm{~km}$ to the south-east, which will be named Ibn Rochd (in Arabic) or Averroes Observatory (Fig. 2, location in the Appendix map). Its functions were listed in the same decree.

What can be considered as the "golden age" of the ISC, including the SPGM, is the period 1934-1951 when Georges Roux (1899-1954), a navy captain, was named head of the SPGM (which changed to "Service" instead of "Section") in 1934. Roux was passionate about meteorology and made great efforts to improve the geophysical sciences at the SPGM. He also launched the publication of the "Annales du Service de Physique du Globe et de Météorologie" (Fig. 3), which, as will be shown later in this article, was the main meteorological/geophysical publication for the region.

\section{Main contributions to geosciences}

This section exposes the main contributions of the ISC to various geoscientific domains, such as meteorology and climatology, oceanography, geophysics (seismology, gravimetry and magnetism), geology and geomorphology. The 


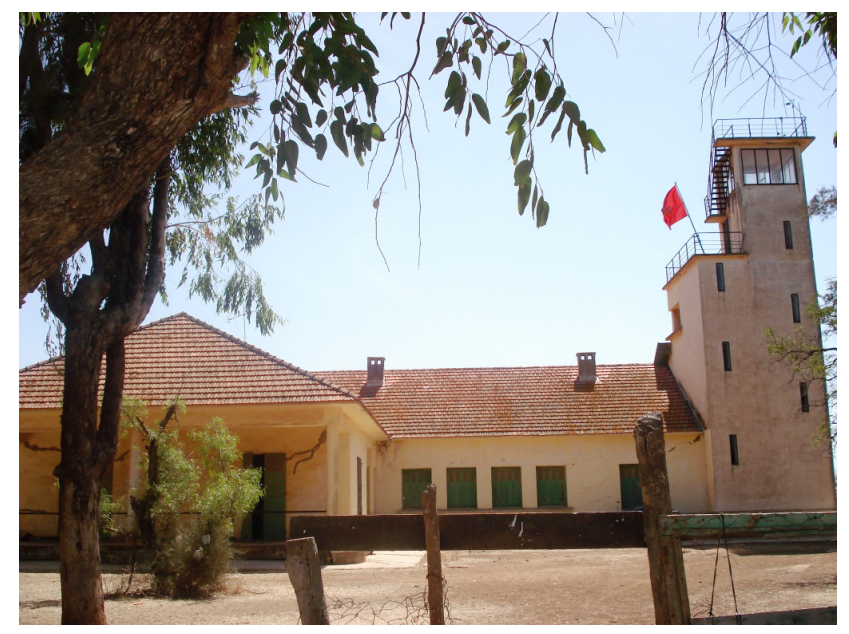

Figure 2. Main building of the Averroes Observatory at Berrechid. Courtesy of T. E. Cherkaoui.

development of research-supporting structures, such as observatories and libraries, is also retraced, together with the associative, editorial and publishing activities.

\subsection{Meteorology}

Initially belonging to the Army in 1916 and afterwards to the "Direction Générale de l'Agriculture", the meteorological network of stations, together with the geophysical survey, was attached to the ISC in 1921 and specifically to the SPGM in 1933. The marine meteorology and swell predictions, previously belonging to the direction of public works, were also attached to the ISC in 1927. After the independence in 1955, the activities slowed down (the last "Annales" include no further meteorological data), and the network of stations and the activities were transferred to the "Direction de l'Air", created in 1961 by a Royal Decree in 1965 (official bulletin 2765, p. 1477).

At its climax (1921-1954), the meteorological network consisted of up to 166 stations in 1934, covering most of the French part of the Protectorate (Fig. 4).

Bulk data from 1921 are still available to date, and the "Annales" include processed data from 1934 to 1954, such as the following:

- The rainfall height by month, together with the number of rainy, snowy and hail days.

- The mean maximum and minimum temperatures by month and other parameters.

- The swell heights.

- Maps of mean maximum (and sometimes minimum) July temperatures, and mean minimum (and sometimes maximum) January temperatures, and annual isohyets (Fig. 4).

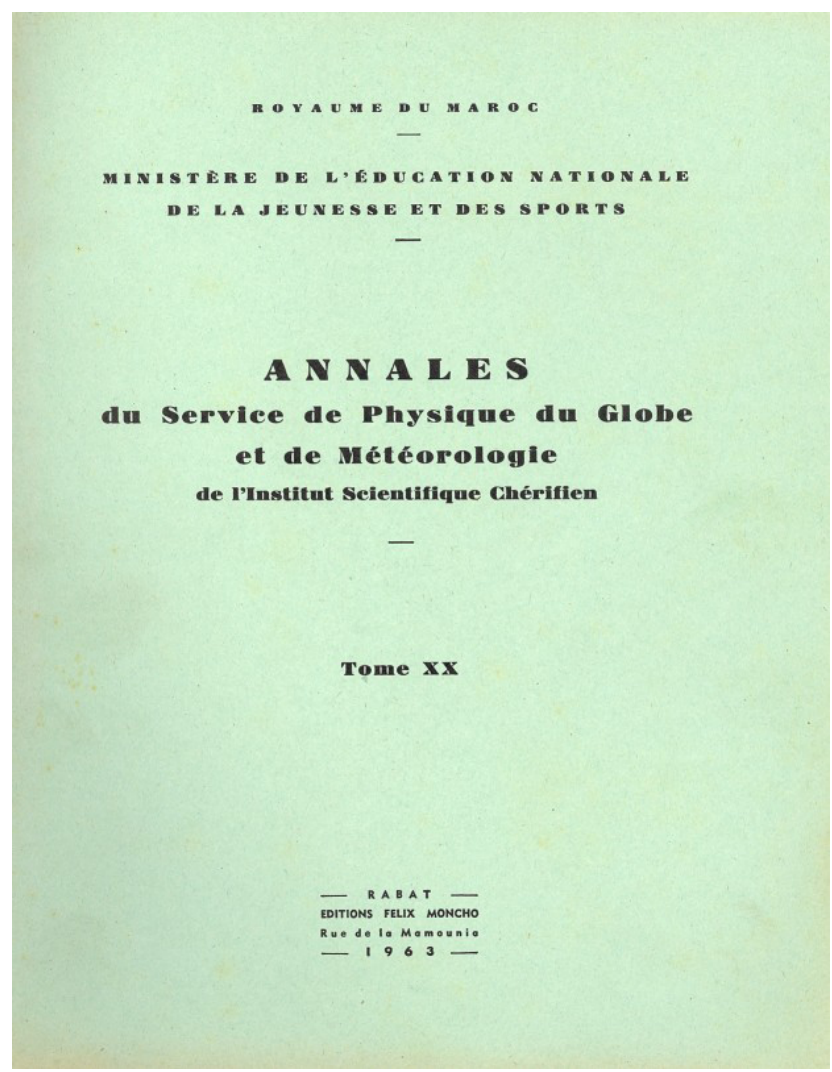

Figure 3. Cover of the "Annales du Service de Physique du Globe et de Météorologie", published from 1938 to 1963 by the SPGM.

It is however noteworthy that the meteorological and climate data are still unknown to the recent studies on the evolution of drought and climate. For instance, the data base used by Stour and Agoumi (2008) and Tramblay et al. (2012) in their studies of drought and precipitation extremes in Morocco starts only in the year 1961. Therefore, all the "Annales" have recently been published online on the website of the ISC in order to provide full access to these data.

\subsection{Oceanography}

Oceanography was vowed to become a major scientific branch at the ISC because of the personal friendship of Dr. Liouville with Prince Albert I of Monaco. Thus, the Prince lent his yacht "Princesse Alice II" to the Protectorate authorities to help conduct the research projects of Dr Liouville. Although the expected projects aborted after the death of the Prince in 1922, Liouville continued the oceanographic research in collaboration with A. Gruvel and R.-Ph. Dollfus from 1923 to 1926 on the vessel Vanneau, and afterwards in 1929 on board the French military vessels Dédaigneuse and Lassigny.

During these campaigns, several parameters were measured such as the water depth and the mineral composition of the bottom sediments, and a provisional map was prepared in 


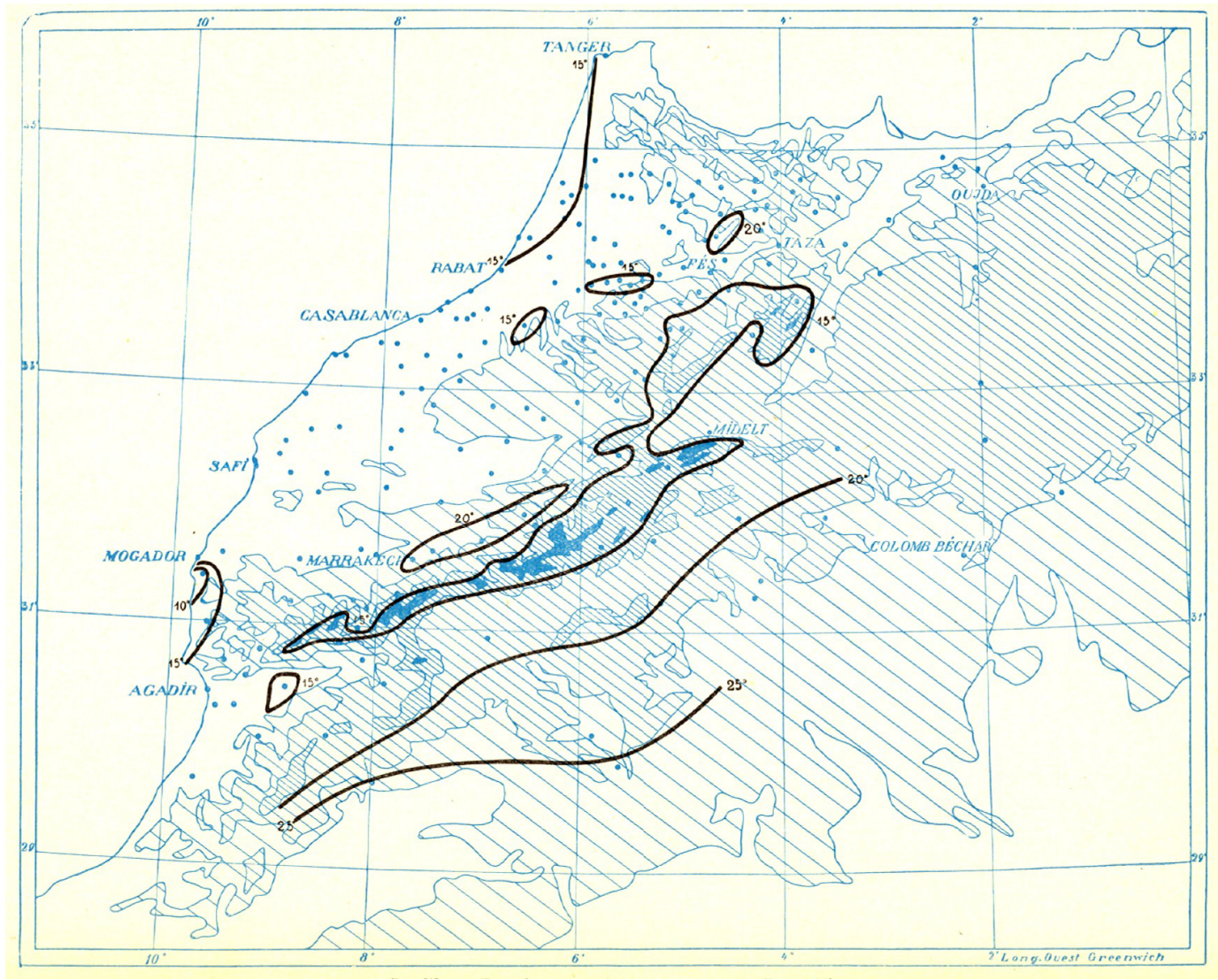

Figure 4. An example of the first meteorological maps prepared by the SPGM in 1934, showing the meteorological network of stations (dots) and the isotherms of the July minimum mean temperatures.

order to help fisheries. The specimens collected by Dr. Liouville and his collaborators can still be viewed at the museum of the Institute.

Later, even though the oceanographic research declined, in particular because of the lack of research vessels and the creation of the "Institut des Pêches du Maroc" in 1947, the ISC remained a rich marine documentation centre to which were sent the publications of several oceanographic centres such as Woods Hole and Scripps institutions, the U.S. Army Corps of Engineers, the Spanish, Chilean, Japanese and Argentinean oceanographic institutes, and is still considered the depositary institution for Morocco of the Intergovernmental Oceanographic Commission.

\subsection{Seismology}

Collecting macroseismic information on Moroccan earthquakes started in 1913 and was mainly accomplished by the meteorological observers, and the seismological questionnaires were initially sent to the "Bureau Central de Séismologie de Strasbourg" in 1932 (Cherkaoui et al., 2007). The results were published in the "Annuaire de l'Institut de Physique du Globe" at Strasbourg and in the "Bulletin de la Société des Sciences Naturelles et Physiques du Maroc".
The first seismographs, two $450 \mathrm{~kg}$ Mainka horizontal seismographs of $10 \mathrm{~s}$ period, with $\mathrm{E}-\mathrm{W}$ and $\mathrm{N}-\mathrm{S}$ components (Fig. 5), were installed in 1934 at the cave of the Averroës Observatory ( $7 \mathrm{~m}$ depth). However, probably because of technical adjustments, recordings did not start before 1 June 1937. Station Averroës was initially attached to the French seismological network (code AVE). Yearly reports (some of which consist of blank pages when no earthquakes were detected!) together with a few analyses and maps (Fig. 6) were regularly published by Jean Debrach in the "Annales" during the period 1934-1954.

In the early 1960s, the SPGM added two Coulomb-Grenet seismographs with a vertical component and 1.2-3 s and $6 \mathrm{~s}$ periods to Averroes Observatory. As a consequence of the Agadir earthquake on 29 February 1960 and the need to develop a seismological array, a second seismograph was installed on 31 October 1964 at Ifrane observatory (IFR, location in the Appendix Fig. A1). The equipment consisted of an electromagnetic, short-period (1.10-1.35 s) APX seismograph with $\mathrm{N}-\mathrm{S}, \mathrm{E}-\mathrm{W}$ and $Z$ components and a Sprengnether photographic paper recorder.

The arrival of several geophysicists from France in the late 1960s and the 1970s (J. Duvergé, M. Stahl, D. Hatzfeld, 


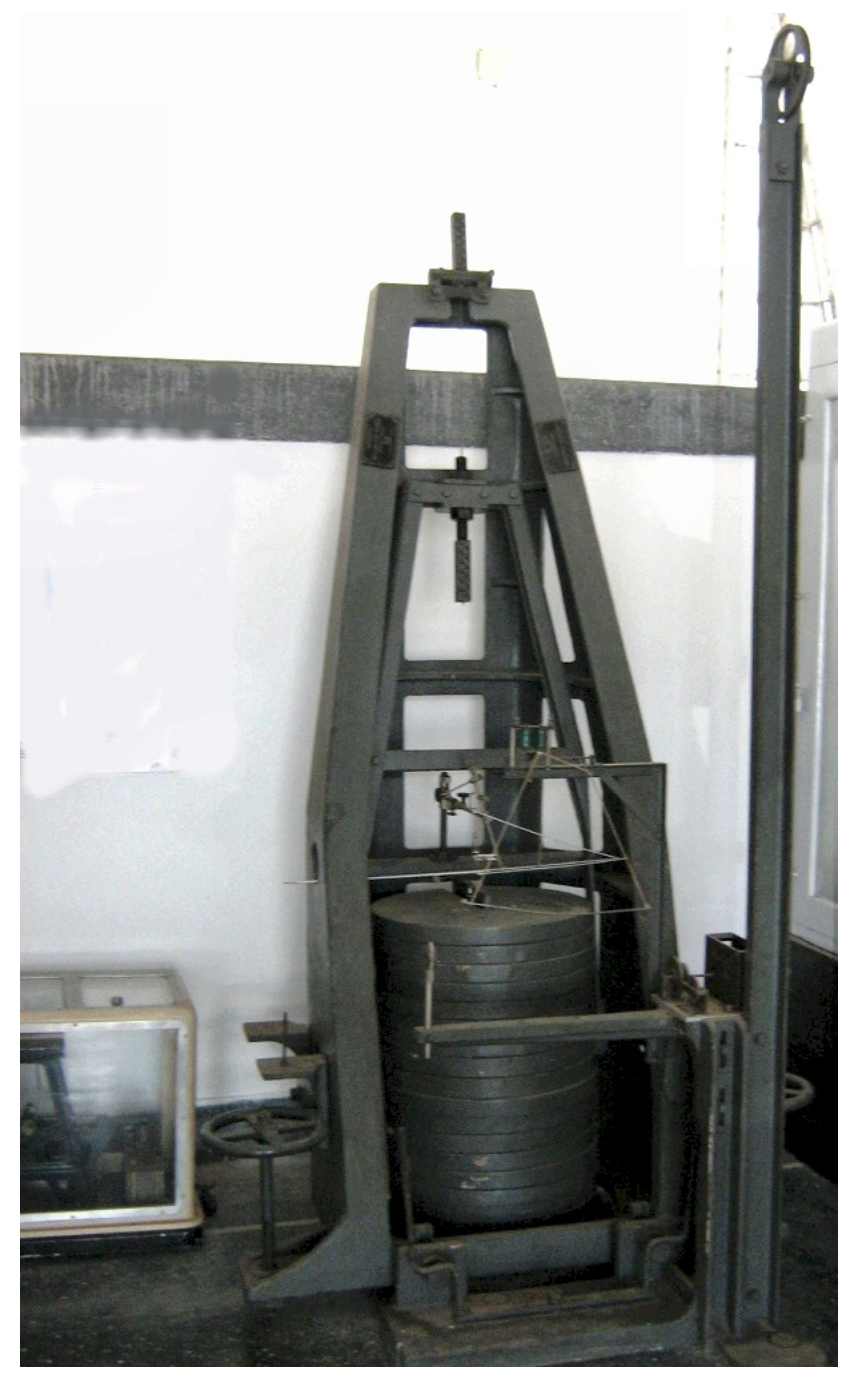

Figure 5. The first seismograph installed in Morocco, a Mainka, at Averroes Observatory in 1934. Courtesy of T. E. Cherkaoui.

M. Frogneux and G. Herquel) helped enhance the seismological network, and up to 16 stations were operational throughout Morocco in 1981 (Cherkaoui et al., 2007; see Fig. A1). These mainly consisted of portable, short period $(1 \mathrm{~s})$ Willmore Mkii at Tiouine Observatory and Sprengnether MEQ800 seismographs elsewhere. In the early 1980s, the French staff was replaced by young Moroccan researchers, most of whom had close ties with French universities (Grenoble, IPG Paris, etc.). Seismic data (phases, arrival times and determinations) were regularly published in the "Bulletin séismologique du Service (changed to "Département" in 1988) de Physique du Globe" from 1964 to the late 1980s, and data were continuously sent to the International Seismological Centre at Kew and published in its bulletin.

\subsection{Gravimetry}

The value of absolute gravity in Morocco was first determined in 1933 by captain Reignier from the Geographical Service of the Army at Averroes Observatory using Mioni equipment. The obtained value of $g$ was 979.563 gal (Roux, 1942). Roux made further measurements from 1936 to 1939 using a Holweck-Lejay no. 67 pendulum, with the objective of determining the secular variation and the effect of temperature on the apparatus. The secular variation could be precisely evaluated because of the stable temperature $\left(20^{\circ} \mathrm{C}\right)$ at the cave. Roux also made determinations in several other places and published the results in 1942.

The first gravimetric map (Bouguer anomaly at a scale of $1 / 1500000$ ) was published in 1950 by the "Institut Géographique National" of France, on the base of the measurements made by the "Compagnie Générale de Géophysique" in 1949-1950 at sites selected by G. Marçais and G. Roux. The starting reference value was $979562.9 \mathrm{mgal}$ at Averroes Observatory. No more gravimetric measurements were conducted by the ISC, and the next ones were carried out by Van den Bosch $(1971,1981)$ for the Ministry of Energy and Mines.

\subsection{Magnetism}

In Morocco, the magnetic measurements were initiated in 1887 at Tangier, and a first general campaign (called "Carnégie") was carried out during 1912 along the Atlantic coastal segment (Debrach, 1935a, b). Other measurements were made in by Homery (1924) and Maurain et al. (1925), and their data were published by Debrach $(1935 \mathrm{a}, \mathrm{b})$.

From 1938 to 1948, Bidault made additional measurements with the help of 6 to 16 stations, using a compasstheodolite "Brunner-Chasselon" (medium model no. 178) and an inclination compass Chasselon (medium model no. 171) (Bidault, 1942).

The first permanent magnetic device, consisting of three La Cour variometers coupled to a slow $\left(15 \mathrm{~mm} \mathrm{~h}^{-1}\right)$ recording system, was installed by F. Soubrane in November 1966 at Averroes Observatory in a $12 \mathrm{~m}$ depth room constructed with amagnetic materials with a mean temperature of $20.8 \pm 0.5^{\circ} \mathrm{C}$ (Soubrane and Sibuet, 1968).

The equipment used in 1967 by Sibuet consisted of three quartz horizontal magnetometers (QHM 180, 181 and 182) for the measurement of the horizontal component, a Chasselon theodolite (old model 178) for calculating declination and calibration of the QHM, and an ELSEC 308 proton magnetometer for the measurement of the vertical component from $H$ and $F$. Recordings were performed according to a La Cour system connected to a photographic paper recorder. The system was operational from 1967 to 1994, and was replaced in 2003 by a Fluxgate magnetometer mounted on a Zeiss 010A theodolite and equipped with an electronic reading device for the measurement of declination and inclination 


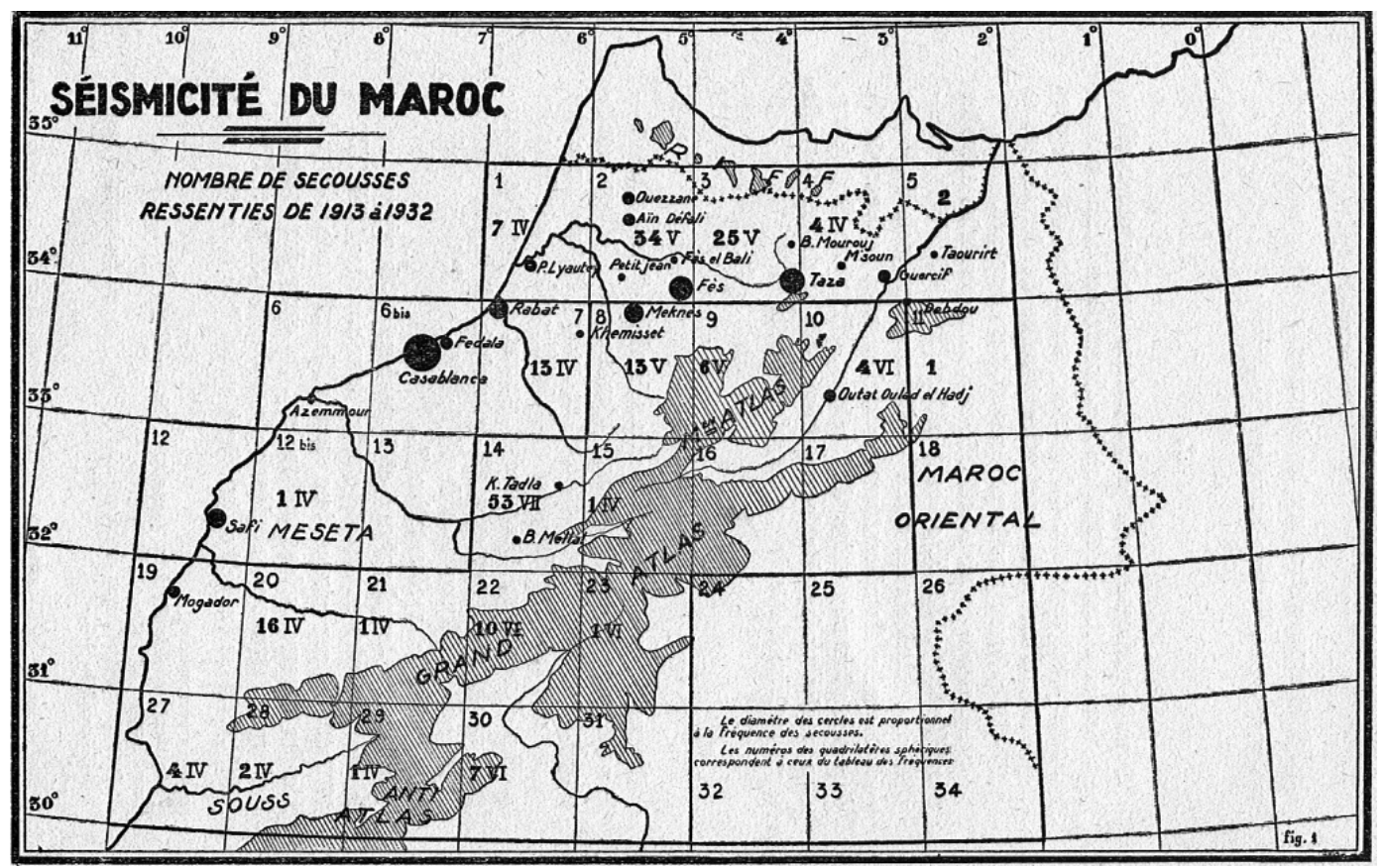

Figure 6. One of the early seismicity maps (1913-1932) of Morocco published by Debrach (1939).

with $1 \mathrm{~s}$ precision, a DIdD system which allows the five magnetic components $(F, D, X, Y$ and $Z$ ) with a sampling step of $5 \mathrm{~s}$ for all data sets, recorded by a PC.

The main results are the transient variations of the magnetic field at Averroes Observatory, published in the thesis of J. C. Sibuet (1969) at Strasbourg.

In spite of continuous technical problems, the Averroes Observatory has remained the reference station for geomagnetic studies in Northwest Africa (e.g. Jankowski and Sucksdorff, 1996), attested by the aeromagnetic surveys, which continue to use the total field measurements at this station (e.g. Di Mauro et al., 2009).

In the 1980s, palaeomagnetic research also became active at the ISC, and one of the first studies on the subject in Morocco was carried out by Najid (1986). More recently, an international program on the magneto-susceptibility of rocks applied to stratigraphy was launched in the late 1990s (Ellwood et al., 1999) and still continues to date. Despite all these research activities, the project of a supporting domestic laboratory at the ISC has never been accomplished.

\subsection{Geology}

Although geology had a rather minor role at the ISC, several studies were carried out by visitor and associate scientists from France and by its own geologists such as Marcel Gigout, who established in the 1950s the stratigraphical sequence and several maps of western Morocco at a 1/200 000 scale, which are still useful today.
It was not before 1980 that geological research became important at the ISC, with the recruitment of several Moroccan scientists, most of which were still preparing their diplomas in French universities (Paris, Marseille, Nancy). Their investigations spread over most Moroccan domains such as the Rif (eastern segment), the High and Middle Atlas, the Meseta (Central Morocco, Rehamna and Jebilet) and the Anti-Atlas. These studies also allowed setting up several structural maps of these domains.

\subsection{Geomorphology and mapping}

Until the 1940s, geomorphology did not exist as a speciality at the ISC, but a major change occurred when Fernand Joly (1917-2010), a former teacher at Oujda, was named at the ISC in 1949. Joly was a very active researcher who founded the "Laboratoire de Géographie Physique" (LGP hereafter) and launched the very ambitious project to create the geomorphological map of Morocco (Fig. 7). Joly also largely contributed to the knowledge on the morphology of the desert area south-east of the High Atlas, and his laboratory was active until he left Morocco in 1964. Gérard Maurer (19241998), who worked at the LGP from 1961 to 1966, also contributed to the knowledge on the morphology of the Rif area and published a map that is still valuable today. The activities of the laboratory continued under the direction of J. Martin, A. André and then Ahmed El Gharbaoui (1940-1999) until his death. The laboratory was recently included in the Department of Earth Sciences. 


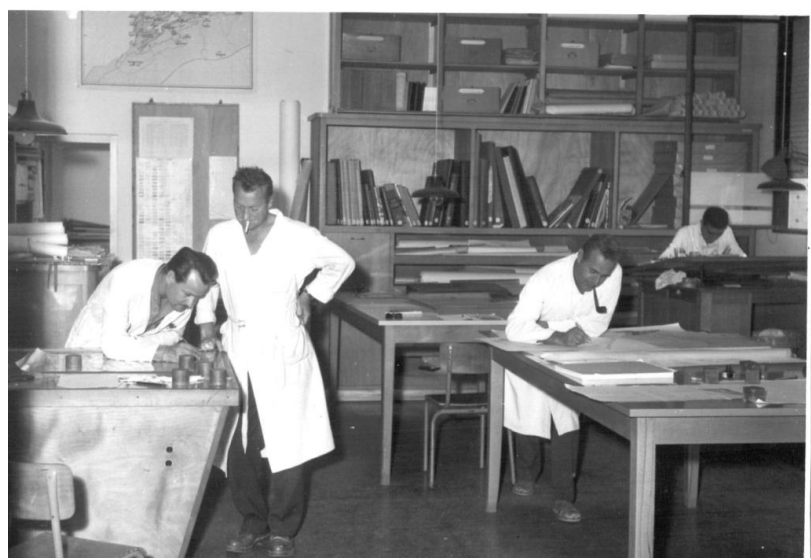

Figure 7. The Laboratory of Physical Geography team at work in 1961. Courtesy of Mrs Duraffour (CNRS, France).

The most relevant achievements of the LGP were the preparation and publication from 1952 to 1975 of several sheets of the "Atlas du Maroc", coordinated by the "Comite Géographique du Maroc", an official committee, together with tens of geomorphological sheets, most of which have remained as drawings. In addition, about 3000 maps (Atlas, topographic, general, etc.) were gathered during this period. Copies of the meteorological archives inherited from the former meteorological service of the SPGM are also deposited at the LGP. In the educational domain, many theses of students at various universities were supervised by El Gharbaoui, but no precise inventory has hitherto been made.

\subsection{Other research domains}

Beside the regular research, there were occasional studies that were carried out at various periods. These studies were ionosphere measurements at Casablanca, actinometric observations, and some descriptions of extreme phenomena such as tsunamis. It is also important to emphasize the pedological studies and maps of Emilio Huguet del Villar (18711951), which were published in the "Travaux de la section de pédologie" of the Society (1950-1957). In the late 1970s, the first remote sensing laboratory in Morocco was founded at the ISC by El Mehdi Alem, a decade before the "Centre Royal de Télédetection Spatiale" was created in 1989. This unit is still active within the Geology Laboratory of the Earth Sciences Department. More recently, the researchers of the ISC have focused on new topics such as geothermal research (Rimi, 1990) and environmental issues, such as the storage of $\mathrm{CO}_{2}$.

\subsection{Research supporting structures}

\subsubsection{Library}

With no doubt, one of the major achievements of the ISC was the founding of a rich library, which was the first scientific documentation centre in Morocco. The library, which was initially attached to the General Library of the Protectorate (National Library at present), contains publications (rare books, journals and maps) of most disciplines of natural history and physics, the oldest ones having been published in 1866. The holdings were continuously fed during the early 20th century by hundreds of volumes provided by gifts (J. Bergeron, L. Gentil, among others), acquisitions and especially by up to 600 exchange agreements with numerous institutions throughout the world. For instance, exchanges were active with the Russian, Polish and Chinese academies of Sciences, the American (New York, Smithsonian, etc.) and German museums (Senckenberg, Berlin) and regional academies, British, French, Spanish, Austrian scientific societies, Japanese museums and centres, etc. Because of financial difficulties, only about 250 exchanges with 170 institutions in 36 countries are still active, and a few books are bought. The total number of volumes is about 17000 .

The most remarkable holdings in geosciences correspond to historical seismological bulletins and reports (e.g. bulletin of the "Bureau Central International de Séismologie" at Strasbourg), regular geological maps (Spain and Portugal in particular), numerous reference volumes in paleontology and stratigraphy and various bulletins of international geological surveys and oceanographic institutions, as covered in the previous sections.

\subsubsection{Observatories}

In conformity with its statute, the ISC built and developed various observatories and stations (Fig. A1). Ifrane observatory was a major meteorological station in the 1920s, and became a main seismological station in 1964 (Fig. 8). Averroes Observatory, which was founded in 1933, hosted most of the meteorological and geophysical activities of the SPGM, as described in the previous sections. Later, other observatories and stations were created, such as the Aouinat Torkoz Saharan Research Centre in 1956, which hosted a seismological station 1991-1994, and Tiouine in 1971, which is a seismological and magnetic observatory reputed by its high-quality recordings because of its location in an abandoned mine.

\subsubsection{Museum}

During the early years, numerous paleontological samples were collected and later deposited in the museum, which was created in the late 1940s. The last partial inventory list of the geological collection contains more than 4700 samples. The most relevant fossils, which have never been revised since their original determination, are the invertebrates collected 


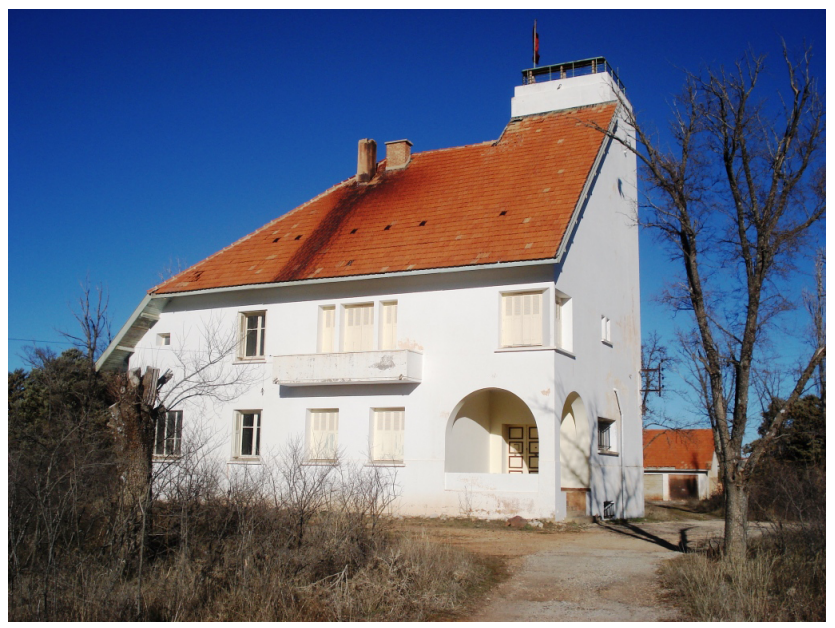

Figure 8. Main building of the Ifrane Observatory. Courtesy of T. E. Cherkaoui.

or offered by A. F. Rolland, G. Lecointre, M. Gigout, J. de Lépiney, L. Russo, J. Bourcart, L. Joleaud and H. Msougar, and the Carboniferous plant remains collected by G. Cogney. The collection of vertebrates is relatively small, mainly consisting of shark teeth (Fedan and Medina, 2009), probably because many of the larger samples (bones and skulls) were transferred to the Faculty of Sciences in the 1960s.

\subsection{Associations, editorial activities and scientific output}

Immediately after its creation, the ISC hosted and funded the first scientific society in Morocco, the "Société des Sciences Naturelles [et "Physiques" afterwards] du Maroc". The society published two regular periodicals, the "Bulletin" (scientific articles) from 1921 to 1975 , and the "Comptes-Rendus" (newsletter) from 1921 to 1972, and other irregular publications such as the "Variétés" (1921-1960), the "Mémoires" (1921-1963) and the "Travaux de la section de pédologie" (1950-1957). The society continued publishing until it was dissolved in 1975. The last issue of the "Bulletin" (no. 55), published in 1975, was immediately replaced by the "Bulletin de l'Institut Scientifique" which continues to date with a peer-reviewed Earth sciences section. In parallel, the ISC published its own "Annales" (1938-1965) and the monograph series "Travaux" (1951-present), which includes the Earth sciences series "Géologie \& Géographie Physique" (23 volumes to date).

With respect to the publications of the ISC researchers, a relatively recent inventory for the period 1962-1999 on the base of Pascal data (Lassri, 2001) indicates 1161 publications, among which 660 were about Earth sciences. Among these, 452 were research articles published in periodicals, and 108 were contributions in monographs. However, the

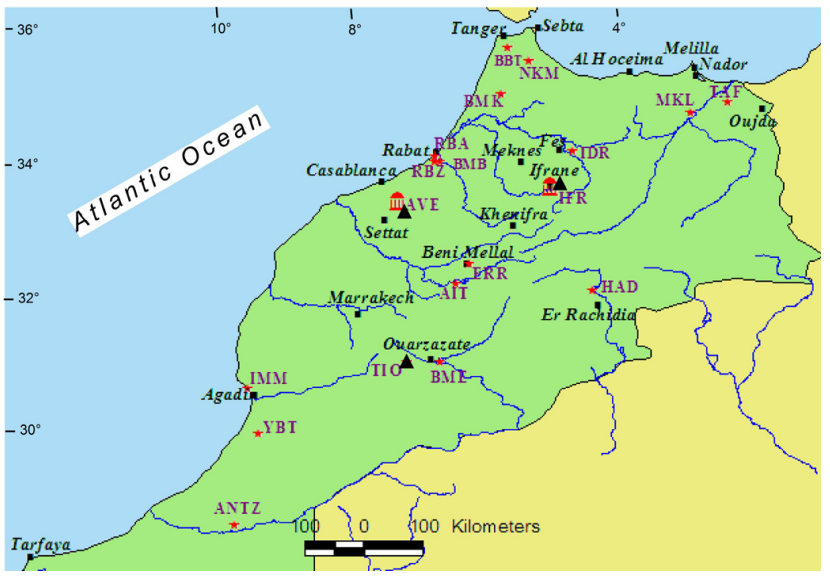

Figure A1. Location of the observatories and stations of the Institut Scientifique in Morocco. Observatories: AVE (Averroes at Berrechid); IFR (Ifrane); TIO (Tiouine); and ANT (Aouinat Torkoz). Other stations were mainly active in the 1970s-1980s. Triangles represent western Mediterranean stations.

largest number of papers (about $97 \%$ ) was published in the last $18 \mathrm{yr}$ of the studied period (1982-1999). Since the number of geoscientists oscillated around 20 , the average number of publications per researcher (33) is probably the highest in Morocco.

\subsection{Education}

Because the ISC belonged, since its creation, to the "Direction générale de l'Instruction publique, des Beaux-Arts et des Antiquités", the education and culture ministry of the Protectorate, its activities and researchers were more or less associated with educational tasks. For instance, the ISC hosted the first undergraduate scientific courses of the "Centre d'Etudes Supérieures Scientifiques de Rabat" from 1940 to 1947, before the construction of the buildings of the Faculty of Sciences in 1947. After the independence of Morocco, the ISC was attached to the Faculty of Sciences, and more generally to the University of Rabat (Mohammed V later), so several new researchers belonged administratively to the faculty and taught there. After the renewal of the official texts on the organization of the university in 1975, according to which the ISC became autonomous, all the young researchers which joined the ISC in the early 1980s had regular undergraduate teaching tasks at the Faculty of Sciences or elsewhere. At present, the main teaching activity of the Institute researchers consists of co-supervising post-graduate students registered at other institutions (because the ISC is not allowed to award diplomas), and several masters and doctoral students have prepared their memoirs within the laboratories of the ISC. 


\section{Partial decline}

The period $1955-1970$ remains poorly documented, as no archives were found at the ISC, probably because they were transferred to the Faculty of Sciences. However, it is clear that several administrative decisions, together with the absence of a clear view on the role of the ISC, contributed to the decline of the geosciences at the institution.

The first decision was the transfer of meteorology to the "Direction de l'Air" in 1965. In fact, the decline of the meteorological survey started after the death of Roux in 1954, and the activity was in a standby state after the independence, waiting for a decision. In addition, the unrest related to the independence of Morocco seems to have interrupted the research activity. As such, the last meteorological data are those of the year 1953 which were published in Tome XIX of the "Annales" in 1959.

The attachment to the newly created University of Rabat and to the Faculty of Sciences in 1959 was also a decision that may have not favoured the development of the ISC because of the different objectives (research vs. teaching) and the difficulty to manage the high-cost maintenance and activities of the SPGM observatories. Also, several new ISC researchers belonged administratively to the above-mentioned faculty and did not have autonomy to develop a research strategy.

Finally, after insurmountable internal discrepancies, the SPGM disappeared as an almost-independent body, as stated in the 1934 creation annals, becoming a simple department within the ISC in 1988. In parallel, its director was named as the head of the "Centre National de Coopération et Planification de la Recherche Scientifique et Technique" (CNCPRST), a research funding and planning body which has, however, created some of its own laboratories, among which is a teleseismic network, which has become the official seismic survey body since 1990 . The ISC remains independent from CNCPRST (shortened to CNR: "Centre National de la Recherche") but some of their projects and laboratories are funded by CNCPRST. However, the Ministry of Higher Education and Research did not explicitly transfer the seismological research activity from the ISC, which is still undertaken within the domains of wave analysis and Earth structure.

In addition to all these governance-related decisions, another major factor was the immobile amount of state funds since the 1980s, which largely became insufficient for the maintenance of the observatories, the replacement of the equipment and the renewal of the documentation. However, an effort has been recently made by the university and the buildings of the observatories have been repaired.

\section{Recent advances}

The recent advances in geosciences by the institute researchers have been mostly accomplished within national and international programs and projects, as several institutions, especially from Western Europe, were interested in developing networks in Northern Africa through strong longstanding partnerships. The main advances concern (i) the installation of broad band seismological stations of the western Mediterranean seismic network at Averroes, Ifrane and Tiouine observatories with real-time monitoring; (ii) the supervision of the Moroccan part of the Topo-Iberia tomographic program (21 stations), and similar programs with the universities of Münster, Oregon and Rice; and (iii) the installation of permanent GPS stations at Averroes since 2008, within the framework of a common program with the Real Observatorio de la Armada at Cadiz (Spain), and at Ifrane (co-supervised by the Massachusetts Institute of Technology). In oceanography, the ISC is a permanent partner within several European programs such as HERMES and others, and its researchers are regularly invited to participate to the cruises. Finally, in stratigraphy, the ISC is a major partner of the International Geological Correlation Program (UNESCO) - Stratigraphy of the Devonian System, and several meetings and field trips have been organized on the Devonian strata of southern Morocco.

\section{Conclusion: overall contribution}

Despite all the difficulties, periods of unrest and absence of visibility (the most frequent question during the last decades has been "what is this institute and what do you do there?"), the contribution of the Institut Scientifique Chérifien to the development of geosciences in Morocco and North Africa during the almost $100 \mathrm{yr}$ of its existence is a major one. After setting the foundations of a modern scientific research institute in Morocco, the most important advances in geosciences were made in meteorology and climatology (until the late 1950s), seismology, magnetism, gravimetry, structural geology, oceanography and geomorphology. In the absence of a clear strategy and political medium- and long-term planning, the progress in geosciences was clearly related to personal initiatives of remarkable researchers and administrators such as Gentil, Liouville, Roux, Joly and Debrach.

The ISC still remains an efficient partner in international projects because of its logistical potential (observatories, vehicles, availability and mobility of researchers, etc.), and its publications are known throughout the world. Moreover, its patrimony (libraries, museum) is unique in Morocco, although the inventory is still incomplete. However, its survival depends on several factors, the most important being the renewal of the equipment, the recruitment of young researchers and technical personnel and a more precise strategy within the present-day scientific and economic context.

Acknowledgements. I would like to thank T.-E. Cherkaoui, former researcher at the SPGM, who provided most illustrations, Bouchta El Fellah (researcher at the LGP), Mr. Abderrahim Alaoui 
(technician at the DPG, formerly SPGM) and Mr. Mohamed Jouadi (former draftsman at the LGP) who provided valuable historical information and photographs. I would also like to express my gratitude to Agustin Udias and an anonymous reviewer for their comments and remarks on the first draft of the manuscript.

Edited by: K. Schlegel

Reviewed by: A. Udias and one anonymous referee

\section{References}

Bidault, G.: Mesures magnétiques, Ann. Serv. Phys. Globe Météorol., Année 1938, 85-90, 1942.

Brives, A.: Contribution à l'étude géologique de l'Atlas marocain, Bull. Soc. Géol. Fr., 4ème série, t. V, 379-398, 1905.

Cherkaoui, T.-E., Bensaid, I., Rimi, A., and Harnafi, M.: Réseau sismologique du Département de Physique du Globe, 1937-2007, Univ. Mohammed V-Agdal, Institut Scientifique, 2007.

Debrach, J.: Déterminations des éléments du champ magnétique terrestre au Maroc effectuées jusqu'en 1934, Mém. Soc. Sci. Nat. Maroc, XLI, 137-145, 1935a.

Debrach, J.: Le magnétisme terrestre au Maroc, Ann. Phys. Globe de la France d'Outremer, 8, 1935b.

Debrach, J.: Sur la sismicité du Maroc. Société Savantes de l'Afrique du Nord; T1, 2 carte; 1939.

Di Mauro, M., Ramdani, F., Fois, M., and Alfonsi, L.: Preliminary results from the first geomagnetic deep sounding in the western sector of the Anti Atlas region, southern Morocco, in: Proceedings of the XIIIth IAGA Workshop on geomagnetic observatory instruments, data acquisition, and processing, edited by: Love, J. J., U.S. Geological Survey Open-File Report 2009-1226, 73-81, 2009.

Ellwood, B. B., Crick, R. E., and El Hassani, A.: The magnetosusceptibility event and cyclostratigraphy (MSEC) method used in geological correlation of Devonian Rocks from Anti-Atlas, Morocco. AAPG Bull., 83, 7, 1119-1134, 1999.

Fedan, B. and Medina, F.: Les vertébrés de la collection du Département des Sciences de la Terre (Institut Scientifique, Rabat): Inventaire et mise en valeur, in: 1st International Congress on North African Vertebrate Palaeontology, Marrakech, 27-29 May 2009, 23-24, 2009.

Gentil, L.: Rapport sur une mission scientifique au Maroc en 1908, Imprimerie Nationale, Paris, 1909.

Gentil, L.: Le Maroc physique, Librairie Félix Alcan, Paris, 1912.

Gotteland, J.: Institut Scientifique Chérifien, historique (19121930). Direction générale de l'Instruction publique, des beauxarts et des antiquités, Rabat, 1931.

Homery, M.: Valeurs des éléments magnétiques dans l'Afrique du Nord au 1er janvier 1921, Ann. Inst. Phys. Globe Univ. Paris \& Bur. Cent. Magnétisme terr., t. 1, p. 43, 1924.

Jankowski, J. and Sucksdorff, C.: Guide of magnetic measurements and observatory practice, International Association of Geomagnetism and Aeronomy, 1996.
Lassri, M.: The scientific and technical output of the Moroccan scientists of the Scientific Institute (University Mohammed V, Faculty of Sciences, Rabat) 1962-1999: an analytical and bibliometric approach, Thesis, Ecole des Sciences de l'Information, Rabat, vol. 1, vol. 2 (directory), 2001.

Maurain, C. B., Eblé, L., Madinhac, Mme de and Homéry, M.: Atlas magnétique, Presses universitaires, Paris, 1925.

Missenard, Y., Michard, A., and Durand-Delga, M.: Major steps in the geological discovery of Morocco, in: Continental evolution: the geology of Morocco, edited by: Michard, A., Saddiqi, O., Chalouan, A., and Frizon de Lamotte, D., Springer-Verlag, Lecture Notes in Geosciences 116, Berlin Heidelberg, 377-392, 2008.

Najid, D.: Palaeomagnetic studies in Morocco, Ph.D. thesis, Univ. Newcastle, 1986, Published in Trav. Inst. Sci. Rabat, sér. Géol. \& Géogr. Phys., 19, 1990.

Rimi, A.: Geothermal gradients and heat flow trends in Morocco, Geothermics, 19, 443-454, 1990.

Roux, G.: Mesures de l'intensité de la pesanteur, Ann. Serv. Phys. Globe et Météorol., Année 1938, 79-83, 1942.

Sibuet, J. C.: Etude des variations transitoires du champ magnétique terrestre à l'Observatoire Averroes, Maroc, et dans les observatoires environnants, Geophys. Engin. Dipl., Univ. Louis Pasteur, Strasbourg, 1969.

Soubrane, F. and Sibuet J. C.: Le nouveau réseau magnétique du Maroc établi en 1967, 1st Edn., 1968.

Stour, L. and Agoumi, A.: Sécheresse climatique au Maroc durant les dernières décennies, Hydroecol. Appl., 16, 215-232, 2008.

Thomson, J.: Travels in the Atlas and Southern Morocco, London, 1889.

Tramblay, Y., Badi, W., Driouech, F., El Adlouni, S., Neppel, L., and Servat, E.: Climate change impacts on extreme precipitation in Morocco, Global Planet. Change, 82-83, 104-114, 2012.

Van den Bosch, J. W. C.: Carte gravimétrique du Maroc (provinces du Nord) au 1/500 000, Notes et Mém. Serv. géol. Maroc, 234, 1971.

Van den Bosch, J. W. D.: Mémoire explicatif de la carte gravimétrique du Maroc (provinces du Nord) au 1/500 000, Notes et Mém. Serv. géol. Maroc, 234 bis, 1981.

\section{Webography}

Site of the Institut Scientifique: www.israbat.ac.ma

Page of the "Annales du Service de Physique du Globe et de Météorologie de l'Institut Scientifique": http://www.israbat.ac.ma/spip.php?article265

Moroccan official bulletins: http://www.sgg.gov.ma/sgg.aspx 